\title{
From placer deposits to technogenic mineral formations: resource and historical perspective (a study of Amur region).
}

\author{
Gadzhi Mirzekhanov ${ }^{1}$ and Zoia Mirzekhanova ${ }^{2}$ \\ ${ }^{1}$ Mining Institute FEB RAS, 51 Turgenev st., Khabarovsk, 680000, Russia; \\ ${ }^{2}$ Institute of Water and Ecology Problems of Far Eastern Branch of Russian Academy of \\ Sciences, 680000, Khabarovsk, Russia
}

\begin{abstract}
Attention to mined gold placers as sources of mineral reserve base replenishment is constantly increasing. We conducted an analysis of the field mining ratio regarding the 170-year period of gold mining history in the region, which is roughly divided into four stages, using the example of gold placer clusters in the Amur region. Each stage has its own peculiarities that determine the nature and methods of alluvial deposits development and the amount of raw material losses. It's shown that previously mined placers within the studied area are being developed continuously. The technogenic complex gets involved into operation almost immediately after mining the undeveloped placer. The obtained results confirm the fact that the indicator of demand for technogenic objects continuously increases with the upward trend from $64 \%$ during the first stage to $80 \%$ at present.
\end{abstract}

\section{Introduction}

The current global economic situation, exacerbated by the pandemic, has revealed many challenges and set priorities for crisis resilience in various economic sectors. Gold mining turned out to be part of a small number of stable industries. This precious metal proved to be the most profitable on stock markets.The countries' might is associated with it; gold always has been and still is the measure of wealth. The "king among the metals" has been consistently sought after for over 6,000 years, which can explain the increased demand for it throughout the world. Gold is a strategic, highly liquid resource supporting national security.

The price for the triple ounce (31.1 g) of gold on the London Metal Exchange once reached 1900 US dollars. Over the past ten years its growth in the domestic market amounted to $200 \%$. And however the global market situation may unfold for this metal and whatever its price, it (along with diamonds) has been and still remains the most significant export commodity (on an equal footing with oil and gas), which covers a significant percentage of income for many nations.

According to experts, if the price of gold continues to rise, most countries with reserves of this metal will be able to increase its production. This includes Russia, the main problem of the gold mining industry development of which is the necessity to replenish the 
resource base in the upcoming years, including by revaluation of already mined alluvial deposits.

Among the world's gold mining producers, the Russian Federation has held a firm leadership position over virtually the entire historical period of gold mining. The Far East, successfully mining precious metals for over 170 years, has been providing and continues to provide the country with a significant share (about 50\%) of metal. Just Khabarovsk Krai and the Amur Oblast account for $20 \%$ of the total gold production in the country or for 42 $\%$ in the Far East region. For example, during this period, according to rough estimates of various authors, about 700 tons were extracted from placer deposits in Khabarovsk Krai only, 950 tons - from Amur Oblast, 2,700 tons - from Magadan Oblast.

\section{Analysis of the problematic situation}

In recent years the significance of alluvial deposits among the total volume of gold production has been gradually decreasing. On the one hand, it is related to the introduction of new mining sites, and on the other hand, to the widely noted depletion of alluvial resources, the main reason for which is the insufficient guaranteed term of commercial reserves development. And at the same time the annual reserves increment is much lower than their extraction. Geological exploration works aimed at identifying and preparing new sites are not always effective, not to mention that the exploration process itself is quite lengthy.

Prospects of reserves increment due to discovery of new alluvial deposits are not great. Therefore, already mined placers are getting on the radar more and more often. Their man-made mineral formations are of interest both from the point of view of localizing a considerable resource potential of the basic metal and, as the research shows, a number of valuable by-products, the content of which was insignificant in the pillar sites[1].

According to some estimates, up to $18 \%$ of the total gold extraction in the country already comes from mining technogenic deposits $[2,3,4]$. The growing interest in them is due to the emergence of new technologies for the extraction of noble metal, which makes it possible to "collect" thin, laminar and dust gold with particles ranging in size from one millimeter to several microns. A big advantage of man-made deposits lies in the fact that the material has already been prepared for treatment - raised from the subsurface and disintegrated. The development of modern gold mining industry in Russia and other countries with similar technological level in the near future will be determined by the degree of involvement of technogenic gold deposits in processing.

So far, many potentially promising targets have been neglected due to lack of necessary information on them. There is no data available regarding such parameters as: flush volume, lixiviation properties of sand, technical support of operation process, gold content in source sands, sand quality, completeness of reclamation measures, etc. A special place among the pivotal characteristics oriented at the prospects of previously mined placers is occupied by the operation period of the site. It is tied to all of the above mentioned parameters.

With the change of standard requirements concerning the quality of resources and economic conditions such information would allow to assess the possibility of prospective use of technogenic formations at previously mined sites.The purpose of this work is to provide an expert assessment of the repeated mining of deposits that would not only demonstrate their past significance, but also reveal their possible future prospects. 


\section{Targets and methods}

The targets of exploration consist of alluvial clusters of the Amur Region; administratively it covers Amur Oblast and Khabarovsk Krai, including Jewish Autonomous Oblast (JAO). The region has a long history of alluvial gold mining, holding leading positions in the country rating. The work is based on the analysis of archive materials, numerous literary sources and the results of practical experience of the authors. Various methods of expert assessments, statistical and bibliometric analysis, generalization and systematization were also used.

\section{Results and discussion}

Previously, we conducted a retrospective analysis of resource and environmental problems arising from the development of placers over various historical periods within the Russian Far East. In this context the whole period of usage of gold bearing sites can be conditionally divided into 4 stages [5]. They are not fixed with clear time-frames since these stages are determined by many factors that have been inherent in a country's socio-economic and political development.Each of the stages has its own peculiarities determined by the conditions of a particular period. They shaped the nature and methods of alluvial deposits development, which, in turn, determined the amount of raw material losses.

There are 32 alluvial clusters identified on the territory of Amur Oblast, Khabarovsk Krai and JAO [5,6,7]. The peculiarities of the development of alluvial deposits within these territories for over more than 170 years of operation were analysed. This period was characterized by a consequent change in the technology of placer deposits development, which resulted in a number of returns of gold mining enterprises to the same sites (Fig. 1). At the same time, technological losses of the valuable component at each preceding stage of development ensured cost-effective development of the deposit in the following stages.

A general picture of the development of the site within the described area over time can be presented as follows.

Due to the meticulous work of E.E. Anert [8] the most detailed information on gold production is available for the first stage (1850-1920). During the first half of the phase removing top soil and sand make-up were carried out predominantly by hand, using simple sluicing equipment. Development of the richest alluvial deposits of Gilyuysky, DzhalindaUrkansky, Dambukinsky, Urusha-Oldoysky, Selemdzhinsky, Amguno-Nizhneamursky, Nimano-Sofiisky and Lanzhinsky clusters started approximately from 1870s and continued until 1903. By this time, main reserves of many alluvial gold deposits had been fully depleted. According to E.E. Anert, they were "so depleted that one could collect anything at all only by sluicing through the stock pile and making wall cutbacks...” [8, p. 407].That is why tailings and residual interstall pillars of various mines along with the whole work sites were widely used for mining for a considerable period of time (1903-1916). For example, in the Amur Oblast the dumping complex for alluvial deposits of this stage was developed by mines of no more than 7 alluvial clusters out of 10 and in the Khabarovsk Krai the repeated works were carried out at the sites of 3 clusters out of 5 .

In the following years by the end of the 20th century the areas involved in alluvial mining were expanded. For example, 4 more alluvial clusters were put in service in the Amur Oblast. At the same time, 2 of them had also been successfully sluicing through the dumping complex almost immediately after mining the undeveloped placer.The new Tumninsky cluster, located in Khabarovsk Krai, started being mined in 1907. The stock piles were also sluiced here. In general, at the first stage the redevelopment of 13 out of 20 alluvial clusters was carried out almost without any breaks due to their rich initial content corresponding to the current economic requirements (Fig. 2). 


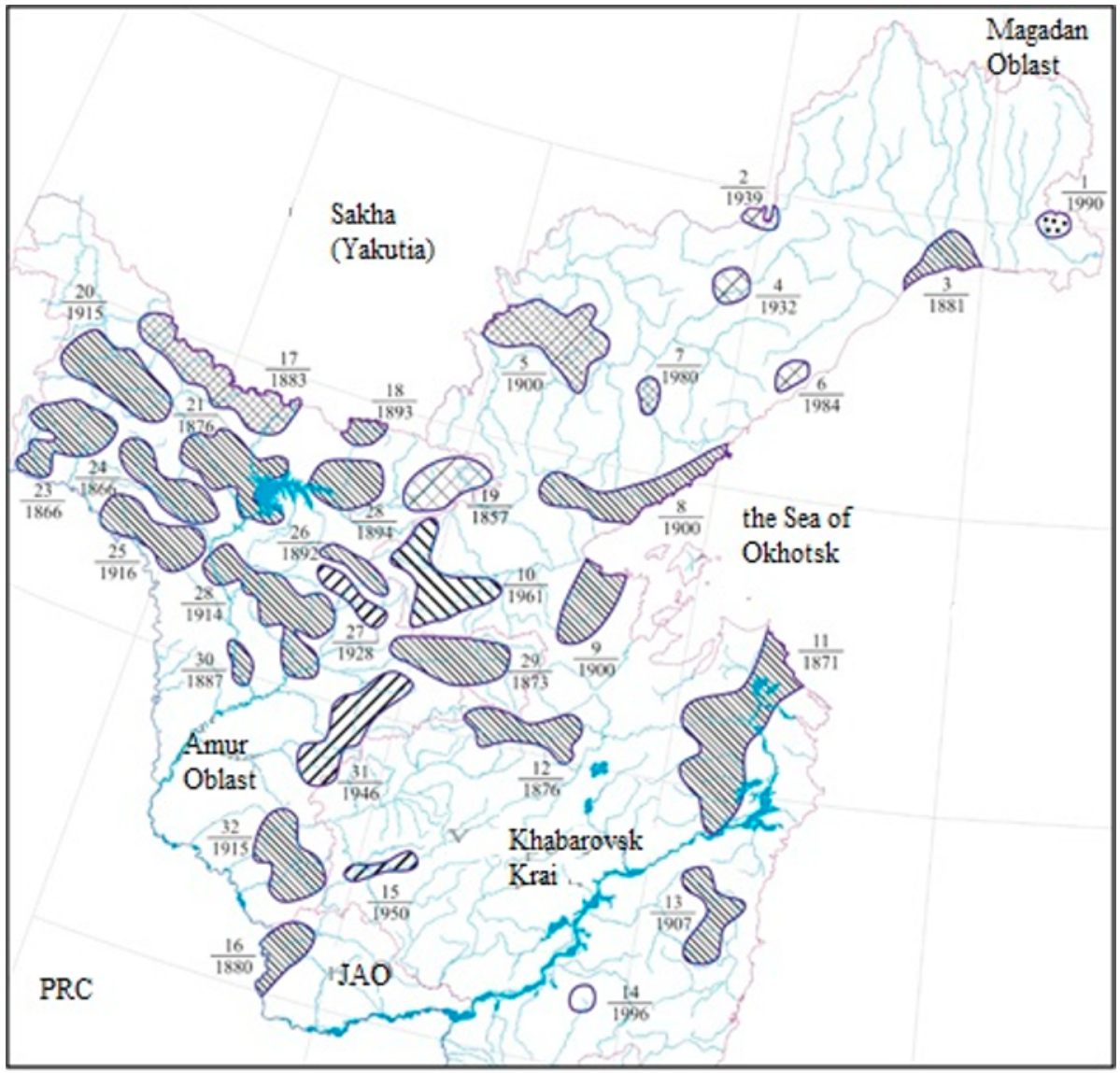

Fig.1. Stages of development of gold placers in the south of the Far East [5] with clarifications Symbols for Fig. 1

Gold placer areas where deposits have been mined:

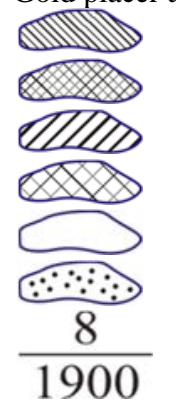

at all four stages, currently being mined;

at all four stages, currently not being mined;

at 2,3,4 stages, currently being mined;

at 2,3,4 stages, currently not being mined;

only at 4th stage, currently being mined;

only at 4th stage, currently not being mined;;

development.

numerator indicates the alluvial area (cluster, field) number; denominator indicates the year of commencement of alluvial field

Placer clusters: 1-Kavinsky; 2-Ogoneksky;3-Lanzhinsky;4-Kurun-Uriakhsky; 5-Uchursky (UlakhanChaidakh); 6-Tukchinsky;7-Odolinsky; 8-Dzhugdzhursky (Pribrezhny); 9-Torom-Tylsky; 10-Udskoy (Chogaro-Udykhinsky);11-Amguno-Nizhneamursky;12-Nimano-Sofiisky (Bureisky); 13-Tumninsky; 14-Sooli-Anyuysky; 15-Gudzhal (Noni)-Iaurinsky; 16-Sutarsky; 17-Gilyuysky; 18-Verkhnetoksky; 19-Kupuri-Maisky; 20-Niukzhinsky; 21-Dambukinsky; 22-Bomnaksky; 23-Urusha-Oldoysky; 24Dzhalinda-Urkansky; 25-Tygda-Ulunginsky; 26-Unia-Bomsky; 27-Norsky (Tuksinsko-NoraEgorsky); 28-Oktiabrsky; 29-Selemdzhinsky; 30-Shimanovsky (Sivaglinsky);31-Severoturansky (Ulminsky); 32-Ivanovsky (Arkharinsky). 
20

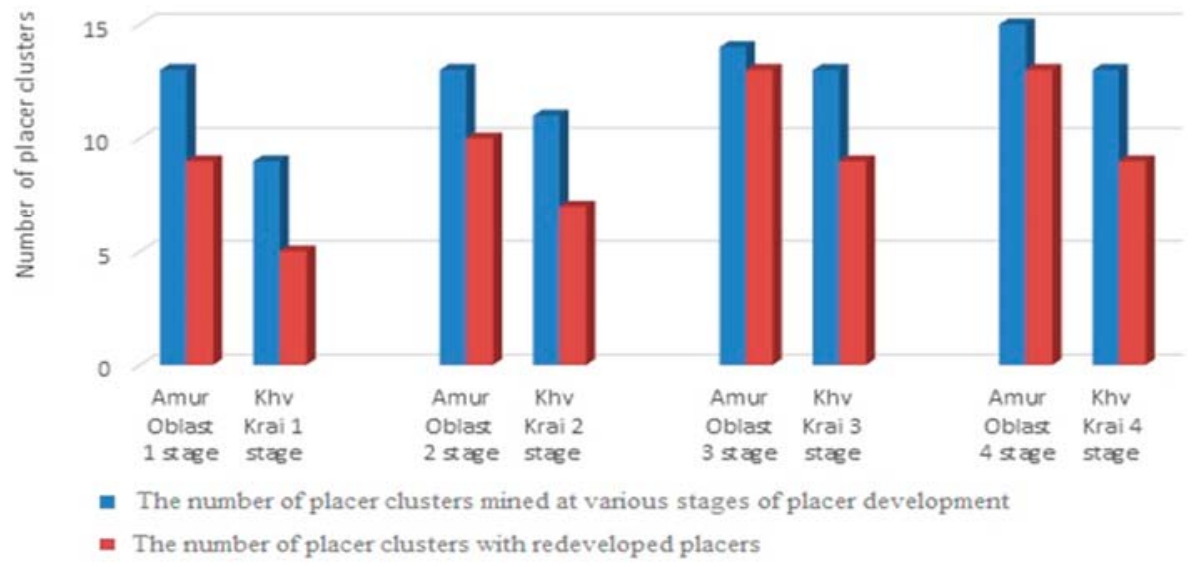

Fig. 2. The distribution of the total number of placer clusters with placers being developed and redeveloped at different stages of mining.

The second stage of gold mining (early 30s - late 60s of the XX century) was a very difficult period for the country: the work was conducted in the hardest economic conditions of slowly recovering economy first after the civil war, then after the second Patriotic War. Despite the fact that many placer clusters were being abandoned (Lanzhinsky, Dzhugdzhursky clusters in Khabarovsk Krai, Niukzhinsky, Bomnaksky, Verkhnetoksky clusters in Amur Oblast) this period was also marked by the discovery of new placer clusters (Ogoneksky, Kurun-Uriakhsky, Chogaro-Udykhinsky in Khabarovsk Krai and Norsky, Severo-Turansky in Amur Oblast). There is no definite information that any placers were involved in redevelopment during this period. However, the wide mechanization of the gold mining operations pushed Amurzoloto to carry out large-scale geological exploration to expand the raw material base within the known placer clusters, where previously the development was carried out without any system. Thus, more than 30 alluvial and 5 dredging sites were singled out within the boundaries of Oktiabrsky, Dambukinskii and Selemdzhinskiiclusters [9]. The conducted assessment allowed to maintain and increase alluvial gold production due to the expansion of the area and revaluation of alluvial deposits exhausted during the first stage, mainly within the boundaries of old placer clusters. This was facilitated by the application of more advanced methods of operation, which made it possible to start developing placers with lower gold content. The degree of engagement of known clusters in redevelopment at the second stage is very high (more than 70\%); basically it secured a "second life" for most alluvial deposits. The redevelopment was carried out among 17 out of 24 placer clusters.It (second life) was made possible due to, among other things, the loss of metal at deposits mined during the first stage. In some cases the useful component content in technogenic complexes (400$1500 \mathrm{mg} / \mathrm{m} 3$ ) exceeded the one in new deposits, the reserves of which are booked in modern times (400-800 mg/m3). Typical examples are the alluvial deposits at the rivers of Ilikan, Daria, Belaya, Mal. Zhorma and others [1].

Due to the aggravation of the state of the mineral resource base during the third stage (70s - 80s of the XX century), gold mining resumed within the clusters abandoned at the second stage. The deposits discovered at the end of the XIX century (during the first stage) with low gold content and located in more difficult to access areas (Odolinsky, KupuriMaisky clusters) started to be actively developed. All in all, during this time the 
development was carried out within 27 placer clusters (14 in Amur Oblast and 13 in Khabarovsk Krai). Alluvial mines of 13 clusters in Amur Oblast and 9 clusters in Khabarovsk Krai were under redevelopment. The rate of returnto previously mined sites was more than $80 \%$.

The modern stage is distinguished by a change in the licensing principle. This allowed new organizations that were not part of the old system between Amurzoloto and Primorzoloto to join the gold mining process. Alluvial sites at each and every placer deposit were licensed, new areas, residual interstall pillars and stock piles from mined placers were studied. However, by the middle of this stage (2000-2010) many enterprises had been dissolved, so the number of placer clusters where the work was still carried out had been reduced to 18. Further mining operations in some of them had been subsequently shut down, but were resumed in other previously discovered clusters. By 2020gold mining operations are being conducted within the boundaries of 20 alluvial clusters, and only 1 of them can be classified as a new one - Soo-li-Anyui, but even this facility started re-mining the refuse ore in 2019.

In general, during this period the mining operations were carried out within 28 placer clusters (15 in Amur Oblast and 13 in Khabarovsk Krai). 22 alluvial clusters were mined and are being mined again (Fig.2).

It should be noted that production targets were developed continuously throughout the 170-year period within 17 out of the 32 identified placer clusters. The development within 4 more clusters was on-and-off over the entire period. The targets within 2 clusters, identified by the end of XIX century, started being mined only during the third stage, and 9 alluvial deposit clusters were identified and developed from the middle of second stage to the present day.

\section{Conclusions}

As can be seen from the above, historically established economic, technological and resource conditions of each stage determined the necessity of engaging in redevelopment of placer deposits of a certain quality. The analysis shows that man-made formations were always in demand. This demand only increased from the first (64\%) to the present stage (80\%). This trend will continue and will probably become even more significant. Due to the continuing depletion of the mineral resource base, the emergence of new technologies, rising prices for gold and social tensions in some remote areas with a traditional focus on the gold mining industry (northern regions of Amur Oblast and Khabarovsk Krai), in the near future present-day losses (technologically explainable at $10 \%$ ) will become very wellfavoured by the industry.

\section{References}

1. G. Mirzekhanov, Z. Mirzekhanova, Resource potential of technogenic mineral formations of alluvial gold deposits (2013)

2. I. Flerov, Mineral resources of Russia, 4, 41-44 (2004)

3. S. Belov, Gold mining industry Information and analytical periodical, 3. 30-37 (2008).

4. Iu. Mamaev, V. Litvintsev, G. Ponomarchuk, Technogenic deposits of noble metals of the Far Eastern region of Russia and their rational development, (2010)

5. Z. Mirzekhanova, G. Mirzekhanov, V. Litvintsev, Pacific geology, 35, 94-106 (2016)

6. A. Sorokin, V. Glotov. Gold-bearing structural and material assemblage of the Far East (1997)

7. I. Vasilev, V. Kapanin, G. Kovtoniuk, V. Melnikov, V. Luzhnov, A. Danilov, A. 
Sorokin Mineral reserve base of Amur Oblast at the turn of the century (2000)

8. E. Anert. Subsoil wealth of the Far East (1929)

9. V. Leshkov, E. Belchenko, B. Guzman, Gold in Russian subsoil (2000) 